\title{
ECOFISIOLOGIA DO JEQUITIBÁ-ROSA E DO JACARANDÁ-DA-BAHIA: MORFOGÊNESE, GERMINAÇÃO E CRESCIMENTO INICIAL
}

\section{ECOPHISIOLOGY OF THE JEQUITIBÁ-ROSA AND OF JACARANDA-DA- BAHIA: MORPHOGENESE, GERMINATION AND INITIAL GROWTH}

\author{
Gizelda Maia RÊGO \\ Orientador(a): Prof. Dr. Edilberto POSSAMAI \\ (Departamento de Fitotecnia e Fitossanitarismo)
}

\begin{abstract}
RESUMO
Estudou-se a influência de alguns fatores morfológicos e ambientais sobre duas espécies florestais nativas, de ocorrência natural na Floresta Atlântica: Cariniana legalis (Martius) O. Kuntze (Lecythidaceae), jequitibá-rosa e de Dalbergia nigra (Vellozo) (Leguminoseae-Papilionoidae), jacarandá-da-bahia, com a finalidade de caracterizar o comportamento ecofisiológico destas espécies dentro do sistema florestal, descrevendo para cada espécie: os caracteres morfológicos das sementes, as características germinativas, a morfologia externa das plântulas e mudas, o efeito de substratos e temperaturas na germinação e vigor das sementes, o efeito de níveis de radiação fotossinteticamente ativa (RFA), sobre o crescimento e concentração de clorofilas foliares em mudas destas espécies. Para avaliação, em laboratório, da capacidade germinativa, estudou-se as temperaturas de $20,25,30,20-30$ e $35^{\circ} \mathrm{C}$ e os substratos: solo floresta, substrato comercial, vermiculita e rolo de papel. No viveiro, com temperatura ambiente, estudou-se os substratos: solo floresta, vermiculita, substrato comercial. Os níveis de (RFA) estudados foram: $34,44,64,70$ e $100 \%$. A descrição das sementes foram efetuadas em relação, a forma, o tamanho, a superfície o hilo, a micrópila e a forma e localização do embrião. Foram descritos os estádios da germinação e os caracteres externos das plântulas e mudas. Com base na porcentagem germinativa e índice de velocidade de emergência, as temperaturas de 30 e $20-30^{\circ} \mathrm{C}$, no substrato vermiculita, favoreceram a germinação e vigor para as duas espécies. No viveiro, o melhor percentual de germinação foi quando se utilizou o solo floresta. O melhor percentual de germinação e vigor foi obtido com a luz branca para o jequitibá-rosa e luz vermelha para o jacarandá-da-bahia. Para as duas espécies o crescimento em diâmetro e matéria seca total, estão relacionados com a maior intensidade de luz, enquanto que a altura, área foliar e clorofilas a e b, aumentaram quando diminuiu a intensidade de luz. Observou-se que o jacarandá-da-bahia apresenta plasticidade e mais tolerância à luz, do que o jequitibá-rosa.

Palavras-chave: espécies florestais, temperatura, luminosidade, plasticidade, clorofila.
\end{abstract}

\begin{abstract}
This work studied the influence of some morphologic and environmental factors about two native forest species of natural occurrence in the Atlantic Forest: Cariniana legalis (Martius) Kuntze, jequitibá-rosa and of Dalbergia nigra (Vellozo), jacaranda-dabahia, with the purpose of characterizing the ecophysiological behavior of these species inside of the forest system, describing for each species: the morphologic characterses of the seeds, the germination characteristic, the external morphology of the seedlings and cuttings, the effect of substrate and temperatures in the germination and vigor of the seeds, the effect of levels of photossintheticaly activates radiation (PAR), about the growth and concentration of the leaf chlorophylls in cuttings of these species. For evaluation, in laboratory, of the germination capacity, it was studied the temperatures of $20,25,30,20-30$ and $35^{\circ} \mathrm{C}$ and the substrate: soil forest, commercial substrate, vermiculita and paper roll. In the nursery, with environment temperature, it was studied the substrate: soil of forest, vermiculita, commercial substrate. The levels of PAR studied were: $34,44,64,70$ and $100 \%$. The description of the seeds was done in according to the shape, size, hilum, the micropyle and the form and location of the embryo. The stage of the germination and the external characteristics of the plantlets and cuttings were described. Based in the percentage of germination and emergency speed index, the temperatures of 30 and $20-30^{\circ} \mathrm{C}$, in the substrate vermiculita, favored the germination and vigour for the two species. In the nursery, the best percent of germination was when the soil forest was used. The best percent of germination and vigour, was obtained with the white light for the jequitibá-rosa and red light for the jacaranda-da-bahia. For the two species, the growth in diameter and total dry matter are related with the largest light intensity, while the height, leaf area and chlorophylls a and $b$, increased when decreased the light intensity. It was observed that the jacaranda-da-bahia presents plasticity and more tolerance to the light than the jequitibá-rosa. Key-words: native forest species, temperature, light intensity, plasticity, chlorophyll.
\end{abstract}

